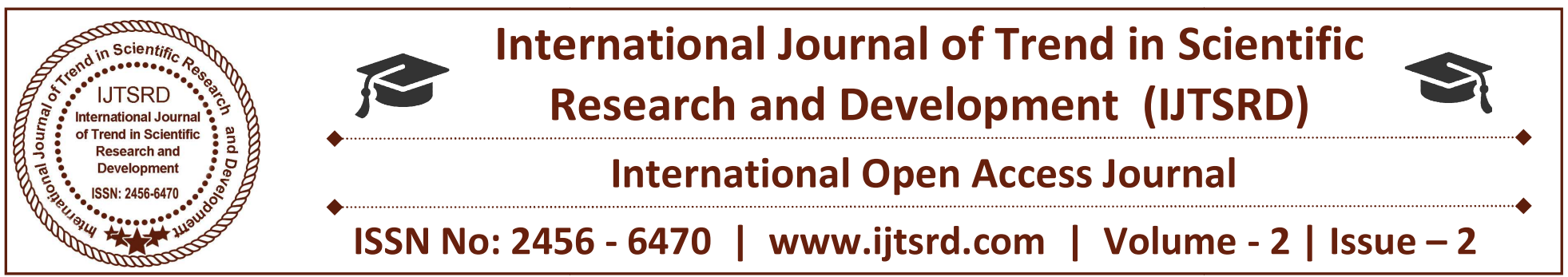

\title{
Characteristics of Rurbanization
}

\author{
Boda Ramesh \\ Geography Department, Osmania University, \\ Hyderabad, India
}

\begin{abstract}
Rurbanisation denotes to the rural area being urbanized, Precisely rural area with the characteristic features of facilities available in area. These include Education (School), Health(PHC), Pucca road to the village, Electrification of the village and establishing new markets. The Rurbanisation posses various characteristic features which has a lot of scope in development of the rural area.
\end{abstract}

Keywords: Rurbanisation, Development, Characteristic feature.

\section{INTRODUCTION}

The world is transforming rapidly. Hereto isolated rural areas are getting connected through the networks of communication. The process of linking initiated by colonization has gained momentum in the second half of the twentieth century. End of colonial era left the world closely linked than ever before. Newly liberated nations busied themselves in reconstruction and reformation of their impoverished rural agrarian societies. Rurbanization is a process of rural transformation. It is not yet caught attention urban planners but it is a prominent development process commonly witnessed in developing countries. Predominantly rural agriculture economy, forms of settlements, lifestyles, and social attitudes are changing and new rurban form is emerging. This paper describes some of the salient features of the process of rurbanization, indicates its origin, and discusses some of the effects the process has brought about. By borrowing metaphor from biology, one can describe suburban sprawl as process of grafting urban lifestyle on rural space. Rurbanization is a process of altering rural forms with pre-selected urban patterns and lifestyles, which creates new genetically altered rurban forms.

\section{OBJECTIVE}

- Basic delivery of facilities to village dwellers.

- Promote integrated development of rural areas with provision of quality housing, better connectivity, employment opportunities and supporting physical and social infrastructure.

- Reduce migration from rural to urban areas due to lack of basic services and sufficient economic activities in rural areas.

- Internal roads within village settlement, Efficient Mass Transportation systems to improve connectivity between urban and rural areas, Public transportation facilities that need to be developed like bus stops, transport depot etc.

- Identification of sanitation facilities that need improvement - sewerage and drainage line for household connection, door to door solid waste collection \& dumping facilities.

\section{METHODOLOGY}

The study focuses this area's secondary information collected from various books, magazines, national and international journals, government reports, publication from various websites focuses on the concept of Rurbanization.

\section{CHARACTERISTICS OF RURBANIZATION}

Rurbanisation is the construction and maintenance of infrastructure and 'urban' buildings within rural 
kebele boundaries, a process which accelerated everywhere following the 2005 election. The infrastructures and buildings involved are:

1. Internal roads and paths

2. Electricity infrastructure

3. Mobile phone infrastructure

4. 4.Water infrastructure: reservoirs; irrigation structures; protected springs, boreholes, wells

5. Health service buildings

6. Schools

7. Kebele buildings: administrative, Farmers' Training Centres, Development Agent and Vet offices, etc.

8. Urban settlements of residential and non-farm business buildings.

9. Approach road.

10. A pucca road starting from the village entrance upto the village chora.

11. Providing drinking water facilities.

12. Construction and renovations of village ponds with bathing ghats.

13. Construction of primary schoolrooms / balwadis / anganwadis.

14. Community Halls.

15. Development of village pasture.

16. Construction of panchayat ghats.

17. Hawada.

18. Electrification

19. Soak-wells / soak - pits

20. Individual / community latrines.

21. Shifting of ukardas at the entrance of the village to an alternate site.

22. Tree plantation along the main road of the village.

23. Afforestation in the gauchar/wasteland.

In each community differences in the difficulty of the terrain, settlement patterns, and the physical locations of these infrastructures and buildings generated differential access to safe water, irrigation, electricity, mobile phone use, modern health and education services, and urban personal services.

\section{CONCLUSION}

Rurbanization is an emerging and potentially most important transformative process, observed in few pockets of the large third world, developing countries. It is fundamentally a process of transformation of rural areas by introduction of certain urban characteristics. It brings about differential growth patterns. However it is not based on the domination paradigm (domination of man over nature or state over citizens) and is fundamentally not an exploitative process. It is more of a regenerative, restorative and revitalizing process. Its emphasis is on healing the wounds suffered during the colonial rule. It positively affects people and environment. Its emphasis is on judicial consumption of resources. It combines traditional knowledge and practices with modern technology. It is a distributive and participatory process, which brings about changes in the lifestyles of participants. Modern technologies such as telecommunication and information technology can further and strengthen the process. It has potential of combining local actions with a global vision. Future oriented rurbanization can make the world a better place to live.

\section{REFERENCES}

1. Barkley, D. (1995). "The Economics of Change In Rural America." American Journal of Agricultural Economics 77: (5): 1252-58 (1995).

2. Browne, W. and L. Swanson. Living With the Minimum: Rural Public Policy. In The Changing American Countryside: Rural People and Places, E.N. Castle (ed.). Lawrence, KS: University Press of Kansas. 1995.

3. Freshwater, D. "Rural America at the Turn of the Century: One Analyst's Perspective." Rural America.15: (3): 2-7 (September 2000).

4. Howarth, W. Land and Word. In The Changing American Countryside: Rural People and Places, E.N. Castle (ed.). Lawrence, KS: University Press of Kansas. 1995.

5. Krugman, P. Geography and Trade. Cambridge, MA: MIT Press. 1991. Roll, E. A History of Economic Thought. London: Faber and Faber. 1973

6. Winters, W. F. "The Rural South: From Shadows to Sunshine." The Rural South: Preparing for the Challenges of the Millennium Series, No. 2. Southern Rural Development Center, Mississippi State, January 2000.

7. Morris, M. and Reed, L. 2009. "Clothing and textiles" in Kraak, A. (ed.) Sectors and Skills: the need for policy alignment. Cape Town: HSRC Press. 